\title{
Pengaruh lama fermentasi dan pemberian aditif molases atau lumpur kecap terhadap fermentabilitas dan kandungan protein kasar silase rumput Gajah cv. Taiwan
}

\author{
Muhamad Rifki B. Ali ${ }^{1}$, Dedi Pratomo ${ }^{1}$, Handi Burhanuddin ${ }^{1}$, Budi Ayuningsih ${ }^{1}$, Tidi \\ Dhalika $^{1}$, Mansyur ${ }^{1}$ dan Iman Hernaman ${ }^{1, a}$ \\ ${ }^{I}$ Fakultas Peternakan Universitas Padjadjaran, Jalan Raya Bandung - Sumedang KM 21 Sumedang 45363 \\ aemail:iman.hernaman@unpad.ac.id
}

\begin{abstract}
Abstrak
Penelitian bertujuan untuk mempelajari pengaruh lama fermentasi dan pemberian aditif molases atau lumpur kecap terhadap fermentabilitas dan kandungan protein kasar silase rumput Gajah cv. Taiwan. Dua puluh empat unit percobaan rumput Gajah yang homogen dialokasikan secara acak ke dalam 8 macam perlakuan lama fermentasi yaitu 3, 6, 9, dan 12 minggu dengan menggunakan aditif molasses dan lumpur kecap sebanyak $5 \%$. Data yang telah terkumpul dilakukan analisis ragam dan dilanjutkan dengan uji Duncan. Hasil menunjukkan bahwa perlakuan mempengaruhi kandungan asam laktat dan ammonia silase $(\mathrm{P}<0,05)$, namun tidak berpengaruh nyata terhadap nilai $\mathrm{pH}$ dan protein kasar. Asam laktat tertinggi $(\mathrm{P}<0,05)$ diperoleh pada perlakuan penggunaan lumpur kecap pada lama fermentasi 3 minggu, sedangkan nilai ammonia tertinggi $(\mathrm{P}<0,05)$ diperoleh pada perlakuan penggunaan lumpur kecap pada lama fermentasi 12 minggu. Semakin lama fermentasi akan semakin meningkat kadar ammonia. Kesimpulan, menunjukkan bahwa jenis aditif dan lama ensilase memberikan pengaruh terhadap kandungan asam laktat dan ammonia namun tidak terhadap nilai $\mathrm{pH}$ dan protein kasar. Hubungan antara lama waktu dengan kadar ammonia/ $\mathrm{N}-\mathrm{NH}_{3}$ adalah pada penggunaan molasses $\mathrm{y}=0,4094 \mathrm{x}+3,0083, \mathrm{R}^{2}=0,8927, \mathrm{r}=$ 0,945 , sedangkan lumpur kecap $\mathrm{y}=0,3156 \mathrm{x}+3,4167, \mathrm{R}^{2}=0,6487, \mathrm{r}=0,805$.
\end{abstract}

Kata kunci: fermentabilitas, lama fermentasi, lumpur kecap, molasses, protein, silase

\section{The effect of fermentation time and molases or soy sauce sludge as additive on fermentability and crude protein of Elephant grass cv. Taiwan silage}

\begin{abstract}
The aim of this research was to study the effect of fermentation time and molasses or soy sauce sludge additives on fermentability and crude protein content of Elephant grass cv. Taiwan silage. Twenty-four homogeneous Elephant grass experimental units were randomly allocated into 8 different types of storage time treatments, namely 3,6,9 and 12 weeks using molasses and soy sauce sludge additives as much as 5\%. The collected data was analyzed for variance and continued with Duncan's test. The results showed that treatment affected lactic acid and ammonia silage $(P<0.05)$, but did not significantly affect $\mathrm{pH}$ and crude protein. The highest lactic acid $(P<0.05)$ was obtained in treatment of using soy sauce sludge for 3 weeks of ensilage, while the highest ammonian $(P<0.05)$ was obtained in treatment of using soy sauce sludge at 12 weeks of fermentation. The longer of storage, ammonia will increase. The conclusion, it showed that type of additive and duration of ensilase have an effect on content of lactic acid and ammonia but not $\mathrm{pH}$ and crude protein. The relationship between length of time ensilage and levels of ammonia was use of molasses $y=0.4094 x+3.0083, R^{2}=0.8927, r=0.945$, while soy sauce sludge $y=0.3156 x+3,4167, R^{2}=0.6487, r=0.805$.
\end{abstract}

Keywords: fermentability, molasses, protein, silage, soy sauce sludge. 


\section{Pendahuluan}

Produktivitas suatu ternak dipengaruhi oleh faktor genetik dan lingkungan. Pakan adalah salah satu faktor lingkungan yang sangat berpengaruh terhadap produktivitas ternak. Ternak sangat membutuhkan pakan untuk kebutuhan hidup pokok, produksi, dan reproduksi. Pakan utama bagi ternak ruminansia adalah hijauan sebagai sumber serat kasar untuk pembentukan VFA (asam lemak terbang) oleh bakteri rumen.

Ketersediaan hijauan di Indonesia pada saat musim hujan cukup berlimpah, sedangkan pada saat musim kemarau ketersediaannya pun berkurang. Kondisi tersebut menyebabkan diperlukannya penerapan teknologi pengawetan hijauan untuk memenuhi kebutuhan pakan bagi ternak ruminansia. Dengan demikian kebutuhan atau konsumsi pakan hijauan oleh ternak ruminansia akan tersedia sepanjang tahun.

Salah satu teknologi pengawetan hijauan yang ada adalah ensilase dengan produk yang dihasilkan berupa silase. Pengolahan pakan dengan cara ensilase dapat memberikan beberapa keuntungan diantaranya, dapat memperkecil kehilangan kandungan nutrien pada bahan dan dapat mencegah pertumbuhan bakteri pembusuk. Prinsip utama pembuatan silase adalah bahan yang akan diensilase harus cukup mengandung karbohidrat terlarut dalam kondisi anaerob secepat mungkin.

Karbohidrat terlarut yang dapat digunakan dalam pembuatan silase adalah molasses atau lumpur kecap (Larangahen, dkk., 2017 dan Alamsyari dkk., 2019). Molases atau lumpur kecap bekerja secara tidak langsung karena hanya sebagai substrat untuk menunjang pertumbuhan Lactobacillus sp. Kondisi ini dapat memperlancar proses fermentasi yang akan membentuk asam- asam organik (Ridwan, dkk., 2020) terutama asam laktat dan sedikit asam asetat, propionat dan butirat. Adanya penambahan molasses atau lumpur kecap diharapkan dapat mempercepat proses fermentasi sehingga suasana asam dan anaerob cepat tercapai (Alamsyari dkk., 2019), akhirnya dapat menekan pertumbuhan bakteri Clostridia yang dapat dilihat secara kimiawi diantaranya berdasarkan kandungan protein dan ammonia.

Silase harus memiliki daya tahan yang kuat, mengingat pembuatan silase dilakukan di musim hujan dan penggunaannya di musim kemarau. Dua periode tersebut memiliki jeda waktu yang cukup lama minimal 3 bulan, oleh karena itu lama waktu fermentasi menjadi penting untuk diperhatikan.

\section{Materi dan Metode Materi Percobaan}

Kultivar rumput Gajah yang digunakan adalah Taiwan dengan umur pemotongan 30 hari. Bahan aditif yang dipakai adalah molasses dan lumpur kecap, masing-masing diperoleh dari limbah pabrik Gula PT. Rajawali, Jati Tujuh Majalengka dan PT. Anugerah Lestari pabrik Kecap Bango, Subang Jawa Barat.

\section{Prosedur Percobaan}

Rumput Gajah dilayukan selama 24 jam, setelah selesai pelayuan kemudian dipotong dengan ukuran 2-3 cm dengan menggunakan chopper. Rumput tersebut ditimbang sebanyak $40 \mathrm{~kg}$ untuk masingmasing tong. Molases atau lumpur kecap dicampurkan dengan rumput Gajah sebanyak 5\% dari berat bahan hingga merata. Campuran tersebut dimasukan ke dalam tong, lalu ditekan dan dipadatkan untuk mengeluarkan oksigen selanjutnya ditutup dengan rapat agar suasana anaerob tercapai. Silase tersebut difermentasi dan diambil sampel untuk dianalisis produk fermentasi dan protein pada minggu ke-3, 6 , 9, dan 12. Sampel tersebut diukur kandungan asam laktat dengan metode Cappucino dan Natalie (1991), ammonia dengan microdifusi cawan Conway (Conway, 1957), derajat keasaman $(\mathrm{pH})$ menggunakan $\mathrm{pH}$ meter dan protein kasar dengan metode Kjeldahl (AOAC, 2005).

\section{Analsis Statistik}

Penelitian dilaksanakan secara eksperimental dengan 8 perlakuan dan 3 ulangan. Adapun perlakuannya adalah:

$$
\begin{gathered}
\mathrm{P} 1=\text { silase rumput Gajah dengan } 5 \% \\
\begin{array}{l}
\text { molasses difermentasi selama } \\
\text { minggu, }
\end{array}
\end{gathered}
$$


$\mathrm{P} 2=$ silase rumput Gajah dengan 5\% molases difermentasi selama 6 minggu,

$\mathrm{P} 3=$ silase rumput Gajah dengan 5\% molasses difermentasi selama 9 minggu,

P4=silase rumput Gajah dengan 5\% molases difermentasi selama 12 minggu,

P5=silase rumput Gajah dengan 5\% lumpur kecap difermentasi selama 3 minggu,

P6 =silase rumput Gajah dengan 5\% lumpur kecap difermentasi selama 6 minggu,

$\mathrm{P} 7=$ silase rumput Gajah dengan 5\% lumpur kecap difermentasi selama 9 minggu,

$\mathrm{P} 8=$ silase rumput Gajah dengan 5\% lumpur kecap difermentasi selama 12 minggu.

Data yang terkumpul dilakukan analisis dengan uji Duncan (Steel dan Torrie, 1993). Hubungan antara perlakuan dengan nilai ammonia ditentukan dengan analisis regresi. Analisis data menggunakan aplikasi SPSS 21 dan Microsoft Excell.

\section{Hasil dan Pembahasan}

Setelah proses ensilase selesai, dihasilkan produk fermentasi dan kadar protein kasar silase rumput Gajah, yang disajikan pada Tabel 1. Asam laktat adalah asam yang dihasilkan oleh bakteri pembentuk asam laktat yang memfermentasikan karbohidrat mudah larut pada substrat. Tingginya asam laktat merupakan ciri bahwa silase tersebut berkualitas baik. Berdasarkan Tabel 1 .
Rataan kandungan asam laktat berkisar antara 4,88-7,13\%. Nilai tersebut masih dalam kisaran standar kandungan asam laktat yang baik, hal ini sesuai dengan pendapat Evans (2004), bahwa asam laktat silase rumput yang baik berkisar antara 2 dan $20 \%$ dari bahan kering. Fermentasi molasses menjadi asam laktat nyata $(\mathrm{P}<0,05)$ tertinggi dicapai pada minggu ke-9 yaitu pada perlakuan P3, sedangkan pada penggunaan lumpur kecap tertinggi diperoleh pada minggu ke-3. Produksi asam laktat lebih tinggi diperoleh pada lumpur kecap dibandingkan dengan molasses $(5,55$ vs $6,13 \%$ ), meskipun selisihnya tidak terlalu jauh. Perbedaan nilai asam laktat diduga akibat karakteristik karbohidrat yang terlarut pada masing-masing bahan aditif. Sementara lama fermentasi diduga bergantung pada daya adaptasi dari bakteri asam laktat terhadap jenis aditif atau sumber karbohidrat yang digunakan. Karbohidrat lumpur kecap hasil analisis menunjukan kandungan bahan ekstrak tanpa nitrogen (BETN) yang lebih tinggi dibandingkan dengan molases, yaitu $77,54 \%$ vs $43,7 \%$. BETN merupakan karbohidrat yang mudah larut dan difermentasi oleh mikroba. Perbedaan jumlah BETN diduga akan memberikan perbedaan dalam menghasilkan asam laktat pada proses ensilase.

Tabel 1. Pengaruh perlakuan terhadap fermentabilitas dan kandungan protein silase rumput Gajah cv Taiwan

\begin{tabular}{lcccccccc}
\hline \multicolumn{1}{c}{ Peubah } & P1 & P2 & P3 & P4 & P5 & P6 & P7 & P8 \\
\hline Asam laktat (\%) & $5,58^{\text {ab }}$ & $5,22^{\mathrm{a}}$ & $6,53^{\mathrm{c}}$ & $4,88^{\mathrm{a}}$ & $7,13^{\mathrm{c}}$ & $5,38^{\mathrm{a}}$ & $6,36^{\mathrm{bc}}$ & $5,64^{\mathrm{ab}}$ \\
$\begin{array}{l}\text { Derajat keasaman } \\
\text { (pH) }\end{array}$ & 3,90 & 3,84 & 3,81 & 3,63 & 3,76 & 3,68 & 3,60 & 3,50 \\
$\begin{array}{l}\text { Ammonia (N-NH }) \\
\text { (mM) }\end{array}$ & $4,27^{\mathrm{a}}$ & $5,22^{\mathrm{ab}}$ & $6,73^{\mathrm{cd}}$ & $6,92^{\mathrm{cd}}$ & $4,02^{\mathrm{a}}$ & $5,75^{\mathrm{bc}}$ & $6,78^{\mathrm{cd}}$ & $7,77^{\mathrm{d}}$ \\
Protein (\%) & 12,22 & 12,97 & 12,95 & 12,22 & 12,22 & 13,20 & 12,85 & 12,15 \\
\hline
\end{tabular}

Keterangan: Superskrip yang berbeda ke arah baris menunjukan berbeda nyata $(\mathrm{P}<0,05)$,

$\mathrm{P} 1=$ silase rumput Gajah dengan 5\% molasses difermentasi selama 3 minggu, P2=silase rumput Gajah dengan 5\% molases difermentasi selama 6 minggu, P3=silase rumput Gajah dengan 5\% molasses difermentasi selama 9 minggu, $\mathrm{P} 4=$ silase rumput Gajah dengan 5\% molases difermentasi selama 12 minggu, P5=silase rumput Gajah dengan 5\% lumpur kecap difermentasi selama 3 minggu, P6=silase rumput Gajah dengan 5\% lumpur kecap difermentasi selama 6 minggu, P7=silase rumput Gajah dengan 5\% lumpur kecap difermentasi selama 9 minggu, $\mathrm{P} 8=$ silase rumput Gajah dengan 5\% lumpur kecap difermentasi selama 12 minggu. 
Derajat keasaman silase $(\mathrm{pH})$ bergantung pada asam organik yang dihasilkan selama proses ensilase. Asam laktat memberikan kontribusi pada perubahan nilai $\mathrm{pH}$ karena merupakan produk utama dari hasil proses fermentasi pada pembuatan silase. Nilai $\mathrm{pH}$ yang diukur tidak menunjukan perbedaaan yang nyata dan rata-rata $<4,2$ sehingga termasuk katagori yang baik (Skerman dan Riveros 1990). Hasil ini tidak sejalan dengan fluktuasi kandungan asam laktat yang menghasilkan perbedaan diantara perlakuan. Hal ini dimungkinkan karena asam yang dihasilkan berupa asam organik yang tergolong sebagai asam lemah (Lunggani 2007) dan selisih diantara perlakuan tidak terlalu besar sehingga perubahan nilai asam laktat secara keseluruhan tidak mempengaruhi nilai $\mathrm{pH}$.

Ammonia merupakan ukuran perombakan protein selama ensilase. Perombakan ini disebabkan oleh bakteri Clostridia (Bureenok et.al., 2006) serta pada kondisi anaerob terjadi proteolysis yang dilakukan enzim protease menghasilkan ammonia. Tingginya ammonia dalam silase menunjukkan tingkat kerusakan protein selama proses fermentasi. Nilai ammonia hasil penelitian berkisar 4,02-7,7 $\mathrm{mM}$ atau setara dengan 6,83-9,78\%, hal ini berarti protein dirombak menjadi ammonia dalam jumlah yang kecil atau protein dalam silase tersebut relatif dapat dipertahankan, karena mengacu dari Departemen Pertanian, (1980) silase yang baik jika mengandung kadar ammonia berkisar 10-15\%. Setelah dianalisis dengan uji Duncan menghasilkan perbedaan yang nyata $(\mathrm{P}<0,05)$, dimana semakin lama fermentasi semakin banyak ammonia yang dihasilkan (Gambar 1).

Hubungan antara lama fermentasi dan kandungan ammonia menunjukkan hubungan yang linear pada silase rumput Gajah baik yang menggunakan aditif molasses maupun lumpur kecap. Hubungan tersebut membentuk regresi linear dengan persamaan regresi masing-masing pada aditif molasses dan lumpur kecap adalah $\mathrm{y}=$ $0,4094 x+3,0083, R^{2}=0,8927, r=0,945$, sedangkan lumpur kecap $\mathrm{y}=0,3156 \mathrm{x}+$ $3,4167, R^{2}=0,6487, r=0,805$. Nilai korelasi untuk masing masing persamaan pada kisaran 0,8-1 yang berarti hubungan yang sangat kuat (Sugiyono, 2007) antara lama fermentasi dengan kandungan ammonia. Asam organik yang diproduksi selama ensilase diduga menyebabkan terjadinya denaturasi protein (Simangunsong dkk., 2016) dan diduga sebagian larut dan menjadi ammonia, meskipun fase stabil sudah terjadi. Kelarutan protein di dalam suatu cairan dipengaruhi oleh beberapa faktor diantaranya $\mathrm{pH}$, suhu, kekuatan ionik dan konstanta dielektrika pelarutnya. Menurut Robinson (1995) protein bersifat amfoter, yaitu dapat bereaksi dengan larutan asam dan basa.

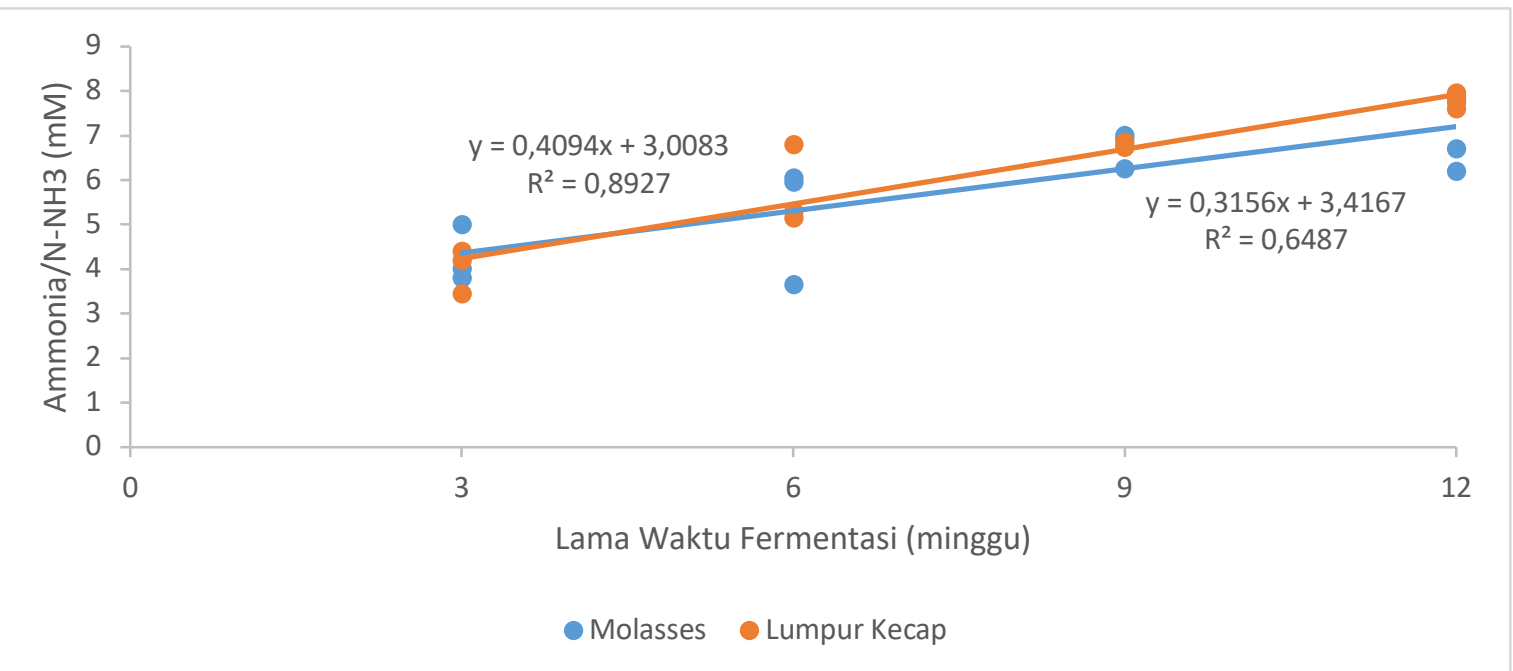

Gambar 1. Hubungan antara lama fermentasi dengan kadar ammonia pada penggunaan aditif molasses dan lumpur kecap 
Protein merupakan nutrien yang penting dalam pakan ternak. Kandungan protein menggambarkan kualitas dari bahan pakan tersebut. Tujuan pembuatan silase salah satunya adalah menjaga atau mempertahankan kualitas bahan yang dibuat silase termasuk di dalamnya kandungan protein. Kadar protein silase yang dihasilkan dalam penelitian ini menunjukkan hasil yang berbeda tidak nyata, padahal kadar ammonia berbeda nyata $(\mathrm{P}<0,05)$. Sebagaimana yang telah dijelaskan sebelumnya bahwa kadar ammonia merupakan indikator kerusakan protein. Jika kadar ammonia tinggi, maka tingkat kerusakan protein juga tinggi. Kondisi yang berbeda tidak nyata disebabkan nitrogen yang terbentuk menjadi ammonia, diduga berasal dari denaturasi protein yang terkandung pada bahan aditif yang digunakan berupa molasses dan lumpur kecap akibat dari proses fermentasi oleh bakteri asam laktat, sedangkan protein rumput Gajah belum banyak yang mengalami denaturasi yang menyebabkan kandungan protein silase rumput Gajah sama. Penggunaan bahan aditif bertujuan untuk mempercepat fermentasi dalam silo yang menghasilkan asam laktat yang berakibat menurunnya $\mathrm{pH}$ silase (Ridwan dkk., 2020). Dengan $\mathrm{pH}$ yang rendah populasi bakteri yang merugikan tidak dapat berkembang dengan baik, sehingga nutrien rumput Gajah termasuk protein akan sedikit mengalami perubahan.

\section{Kesimpulan}

Jenis aditif dan lama ensilase memberikan pengaruh terhadap kandungan asam laktat dan ammonia, namun tidak terhadap nilai $\mathrm{pH}$ dan protein kasar. Semakin lama ensilase semakin tinggi kandungan ammonianya, namun respon tersebut tidak terjadi pada asam laktat. Hubungan antara lama waktu dengan kadar ammonia/ $\mathrm{N}^{-\mathrm{NH}_{3}}$ adalah pada penggunaan molases $y=0,4094 x+3,0083, R^{2}=0,8927, r=0,945$, sedangkan lumpur kecap $\mathrm{y}=0,3156 \mathrm{x}+$ $3,4167, R^{2}=0,6487, r=0,805$

\section{Ucapan Terimakasih}

Terimakasih disampaikan kepada Laboratorium Produksi Ternak Perah dan Laboratorium Nutrisi Ternak Ruminansia dan Kimia Makanan Ternak Fakultas Peternakan Universitas Padjadjaran yang telah menyediakan tempat untuk dilakukan penelitian. Terimakasih Juga kepada Ir Tidi Dhalika, MS yang menyediakan rumput Gajah cv Taiwan sebagai bahan baku penelitian.

\section{Daftar Pustaka}

Alamsyari, Mansyur, I. Hernaman, I. Susilawati, N.P. Indriani, R. Z. Islami, T. Dhalika. 2019. Karakteristik fisik limbah padat pembuatan tepung aren (Arenga pinnata Merr.) hasil fermentasi anaerob dengan aditif molases, lumpur kecap dan urea. Jurnal Nutrisi Ternak Tropis dan Ilmu Pakan 1(1):1-5

AOAC. 2005. Official Method of Analysis of the Association of Official Analitycal Chemist. Benyamin Franklin Station, Washington, D.C

Bureenok, S., T. Namihira, S. Mizumachi, Y. Kawamoto, dan T. Nakada. 2006. The effect of epiphytic lactic acid bacteria with or without different by product from defatted rice bran and green tea waste on Napiergrass (Pennisetum purpureum Shumach) silage fermentation. J. Sci. Food Agric. 86: 11073-1077

Cappucino, J.G. dan S. Natalie. 1991. Microbiology: A Laboratory Manual. Rockland Community College State University of New York.

Conway, E.J. 1957. Microdiffusion of Analysis of Assosiation Official Analitycal Chemist: Goergia Press.

Departemen Pertanian. 1980. Silase sebagai Makanan Ternak. Departemen Pertanian. Balai Informasi Pertanian, Ciawi Bogor.

Evans, B. 2004. Interpreting Grass Silage Analysis. Grassland Development Centre. Institute of Grassland and Environtmental Research. Aberystwyth, Ceredigion. United Kingdom

Larangahen, A, B. Bagau, M. R. Imbar, dan H. Liwe. 2017. Pengaruh penambahan molases terhadap kualitas fisik dan kimia silase kulit pisang sepatu 
(Mussa paradisiaca formatypica). Jurnal Zootek, 37 (1): 156 - 166

Lunggani, A.T. 2007. Kemampuan bakteri asam laktat dalam menghambat pertumbuhan dan produksi aflatoksin B2 Aspergilllus flavus. BIOMA 9 (2) : $45-51$

Ridwan M., D. Saefulhadjar, dan I. Hernaman. 2020. Kadar asam laktat, amonia dan $p H$ silase limbah singkong dengan pemberian molases berbeda.Majalah Ilmiah Peternakan 23 (1): 30-35

Simangunsong, D.S., Nurliana, Sulasmi, Ismail, T.R. Ferasyi, dan M. Isa. 2016. Efek pencelupan karkas ayam pedaging dalam larutan asam asetat dan asam sitrat terhadap penurunan kadar protein. Jurnal Medika Veterinaria 10 (2): 159-161

Skerman, P. J. and F. Riveros. 1990. Tropical Grasses. Food and Agriculture Organiozation of the United. Nations. Rome.

Robinson, T., 1995, Kandungan Organik Tumbuhan Tinggi Edisi VI, Hal 191216, Diterjemahkan oleh Kosasih Padmawinata, ITB, Bandung.

Steel, R.G.D. and J.H. Torrie. 1993. Prinsip dan Prosedur Statistika. Edisi Kedua. PT Gramedia Pustaka, Jakarta (Diterjemahkan oleh B. Sumantri).

Sugiyono, 2007. Metode Penelitian Pendidikan Pendekatan Kuantitatif, Kualitatif, dan $R \& D$. Bandung: ALFABETA 